\title{
Pengaruh Kualitas Produk Terhadap Citra Merk Dan Dampaknya Terhadap Keputusan Pembelian Konsumen
}

\author{
Dinti Gircela ${ }^{1}$, Lela Nurlaela Wati ${ }^{2}$ \\ ${ }^{1}$ STIE Muhammadiyah Jakarta, dinti@ stiemj.ac.id \\ ${ }^{2}$ STIE Muhammadiyah Jakarta, lela@ stiemj.ac.id
}

\begin{abstract}
ABSTRAK
Penelitian ini bertujuan untuk menganalisis bukti empiris pengaruh kualitas produk dan citra merk produk berleabel alfamart terhadap keputusan pembelian konsumen pada alfamart kramat pulo 2. Sample yang diperoleh sebanyak 100 responden. Teknik pengambilan sample meggunakan non probability sampling, yaitu teknik pengambilan sampel yang memberikan peluang yang sama bagi setiap unsur (anggota) populasi untuk dipilih menjadi anggota sample. Hasil penelitian menunjukkan bahwa kualitas produk berpengaruh positif dan signifikan terhadap citra merk, sehingga jika kualitas produk semakin baik maka citra merk akan semakin meningkat. Secara empiris citra merk berpengaruh positif dan signifikan terhadap keputusan pembelian sehingga jika citra merk dari produk tersebut semakin melekat dibenak konsumen maka keputusan pembelian akan semakin meningkat. Selanjutnya pengujian secara empiris, kualitas produk berpengaruh positif dan signifikan terhadap keputusan pembelian. Pada hipotesis keempat, kualitas produk berpengaruh positif dan signifikan terhadap keputusan pembelian konsumen melalui citra merk.
\end{abstract}

Kata Kunci : kualitas produk, citra merk dan keputusan pembelian

\begin{abstract}
This study aims to analyze empirical evidence of the influence of product quality and brand image of Alfamart-labeled products on consumer purchasing decisions on Alfamart Kramat Pulo 2. Smple obtained by 100 respondents. The sampling technique uses non probability sampling, which is a sampling technique that provides equal opportunities for each element (member) of the population to be selected as sample members. The results showed that product quality had a positive and significant effect on brand image, so that if product quality was getting better the brand image would increase. Empirically the brand image has a positive and significant influence on purchasing decisions so that if the brand image of the product is increasingly attached to the minds of consumers, purchasing decisions will increase. Furthermore, empirical testing, product quality has a positive and significant effect on purchasing decisions. In the fourth hypothesis, product quality has a positive and significant effect on consumer purchasing decisions through brand image.
\end{abstract}

Keywords: product quality, brand image and purchasing decisions 


\section{PENDAHULUAN}

Tujuan utama dari perusahaan adalah meningkatkan kesadaran akan mereknya untuk menjadikan mereknya berada diposisi puncak pikiran konsumen. Perusahaan ritel harus bisa menjaga kesadaran terhadap merek karena posisi merek dijaman sekarang menjadi sangat penting, bukan hanya identitas nama dan simbol saja untuk membedakan dengan para pesainganya tetapi merek juga merupakan faktor yang menentukan sukses tidaknya suatu perusahaan. Merek juga menjadi suatu pembeda antara produk satu dengan produk lainnya diantara komoditas yang ada dan merek juga berpengaruh terhadap keputusan pembelian konsumen, seseorang akan membeli produk dengan merek yang sudah dikenal (Maranatha, 2013).

Pada saat konsumen mengambil keputusan untuk membeli suatu produk sebenarnya mereka telah memiliki alasan-alasan tertentu dalam memilih produk tersebut, misalnya mereka merasa puas dengan kualitas dan pelayanan yang ditawarkan produk tersebut. Tidak sedikit konsumen yang membeli suatu produk secara spontanitas, artinya konsumen membeli produk tersebut tanpa ada rencana untuk membeli sebelumnya atau tanpa adanya pertimbangan-pertimbangan khusus ketika memutuskan untuk membeli dan ada pula konsumen yang membeli barang hanya berdasarkan kebutuhan akan suatu barang ( Paramitasari, 2013).

Berdasarkan uraian diatas mengenai keterkaitan kualitas produk, citra merk, dan keputusan pembelian, membuat penulis tertarik untuk melakukan penelitian pada toko Alfamart Kramat Pulo 2. Hasil pengamatan penulis menemukan beberapa masalah yang terjadi pada alfamart, yaitu penjualan produk berlabel alfamart lebih rendah dibandingkan dengan produk lainnya hal tersebut dapat dibuktikan dari laporan posisi mutasi pada toko Alfamart Kramat Pulo 2, periode 01-Feb-2016 s/d 29-Feb-2016. Secara lengkap data perbandingan dapat dilihat pada tabel 1 berikut ini :

Tabel 1. Penjualan Produk Berlabel Alfamart dan Non Alfamart

\begin{tabular}{|l|l|c|c|}
\hline \multirow{2}{*}{ No. } & \multirow{2}{*}{ JENIS PRODUK } & \multicolumn{2}{|c|}{ TOTAL PENJUALAN } \\
\cline { 3 - 4 } & $\begin{array}{c}\text { PRODUK } \\
\text { BERLABEL } \\
\text { ALFAMART }\end{array}$ & $\begin{array}{c}\text { PRODUK } \\
\text { BERLABEL } \\
\text { LAIN }\end{array}$ \\
\hline 1. & Gula pasir & 5 & 19 \\
\hline 2. & Air mineral pet & 233 & 427 \\
\hline 3. & Meisses cokelat & 25 & 26 \\
\hline 4. & Mie goreng & 32 & 190 \\
\hline
\end{tabular}

Sumber : Laporan posisi mutasi-TK.Kramat Pulo 2

Menurut data laporan tersebut dapat diartikan bahwa keputusan pembelian konsumen pada produk yang berlabel alfamart lebih rendah dibandingkan produk-produk sejenis lainnya. Masyarakat lebih memilih produk lain yang dijual di pasar modern dan warung-warung yang telah memiliki citra merek yang sudah dikenal baik dengan kualitas produk yang sudah tidak di ragukan.

Survey yang dilakukan oleh Oktora (2010), dan Anandia (2015), mengenai kualitas produk terhadap citra merek mendapatkan hasil kualitas produk berpengaruh positif dan signifikan terhadap citra merek. Sementara Paramitasari (2013), Gusniar (2010), melakukan penelitian mengenai pengaruh citra merek terhadap keputusan pembelian dan menghasilkan bahwa citra merek berpengaruh positif dan signifikan terhadap keputusan pembelian.

Berdasarkan survey terdahulu yang dilakukan oleh Prabowo (2013), dan Baihakki (2013), mengenai kualitas produk terhadap keputusan pembelian, mereka 


\section{URNAL EKOBIS: EKONOMI, BISNIS \& MANAJEMEN Vol X Nomor X (year)}

memperoleh temuan yang sama dimana kualitas produk berpengaruh positif dan signifikan terhadap keputusan pembelian. Namun, Taslim (2014), menemukan hasil yang berbeda, dimana kualitas produk berpengaruh positif tetapi tidak signifikan terhadap keputusan pembelian begitu juga dengan hasil penelitian Fauziah (2013), yang memperoleh temuan bertolak belakang dimana kualitas produk memiliki pengaruh negatif dan tidak signifikan terhadap keputusan pembelian. Erdwansyah (2013), menemukan bahwa kualitas produk tidak berpengaruh pada keputusan pembelian melalui citra merek.

Berdasarkan uraian di atas, tujuan penelitian ini adalah untuk menguji pengaruh kualitas produk terhadap citra merk produk berlabel alfamart dan dampaknya terhadap keputusan pembelian konsumen pada alfamart kramat pulo 2 .

\section{KAJIAN LITERATUR \\ Kualitas Produk}

Menurut Kotler dan Armstrong (2012:283) "Kualitas produk adalah kemampuan sebuah produk dalam memperagakan fungsiya, hal ini termasuk keseluruhan durabilitas, reliabilitas, ketepatan, kemudahan pengoperasian, dan reparasi produk, juga atribut produk lainnya".

\section{Citra Merek (Brand Image)}

Surachman (2008) mendefinisikan citra merek sebagai bagian dari merek yang dapat dikenali namun tidak dapat diucapkan, seperti lambang, desain huruf atau warna khusus, atau persepsi pelanggan atas sebuah produk atau jasa yang diwakili oleh mereknya.

\section{Keputusan pembelian}

Pada umumnya, keputusan pembelian konsumen adalah membeli merek yang paling disukai (Kotler dan Amstrsong, 2008).

Menurut Kotler dan Keller (2007) terdapat lima tahapan dalam proses pembelian konsumen yakni:

1. Pengenalan Masalah

Proses pembelian dimulai ketika pembeli mengenali masalah atau kebutuhan. Kebutuhan dapat dicetuskan oleh rangsangan internal dan eksternal.

2. Pencarian Informasi

Konsumen terangsang kebutuhannya akan terdorong untuk mencari informasi yang lebih banyak. Selanjutnya dapat dibagi ke dalam dua tingkat rangsangan yakni:

a. Penguatan perhatian

Pada tingkat ini, orang hanya sekedar lebih peka terhadap informasi produk.

b. Mulai aktif mencari informasi

c. Mencari bahan bacaan, menelpon teman dan mengujungi toko untuk mempelajari produk tertentu.

3. Evaluasi alternatif

Bagaimana konsumen mengelola informasi merk yang bersaing dan membuat penilaian akhir. Tidak ada proses evaluasi tunggal sederhana yang digunakan oleh semua konsumen dalam semua situasi pembelian. Terdapat beberapa keputusan dan model terbaru yang memandang evaluasi konsumen sebagai proses yang beroreintasi kognetif. Artinya, model ini menganggap konsumen membentuk penilaian atas produk dengan sangat sadar dan rasional.

4. Keputusan Pembelian

Dalam tahap evaluasi, konsumen membentuk preferensi merk yang ada di dalam kumpulan pilihan. Juga konsumen bisa membentuk niat membeli merk yang paling 
disukai. Dalam melaksanakan maksud pembelian, konsumen dapat mengambil lima sub keputusan yakni :
a. Merk
b. Dealer
c. Kuantitas
d. Waktu, dan
e. Metode pembayaran

\section{Kerangka Pikir dan Hipotesis}

Kualitas dapat diberi pengertian sebagai totalitas dari karakteristik suatu produk yang menunjang kemampuannya untuk memenuhi kebutuhan. Kualitas sering kali diartikan sebagai segala sesuatu yang memuaskan konsumen atau sesuai dengan persyaratan atau kebutuhan. Kualitas produk sangat berpengaruh terhadap brand image, apabila kualitas produk baik maka secara langsung akan memberi pengaruh positif terhadap brand image hingga sampai ke tahap pengambilan keputusan pembelian konsumen terhadap produk tersebut. Citra merek yang kuat memberikan sejumlah keunggulan, seperti posisi pasar yang lebih superior dibandingkan pesaing, Oktora (2010).

Oktora (2010) dan Anandia (2015), melakukan penelitian mengenai kualitas produk terhadap citra merek dan mendapatkan hasil dimana kualitas produk berpengaruh positif dan signifikan terhadap citra merek (Brand Image).

Mengacu pada uraian diatas maka peneliti membuat hipotesis pertama sebagai berikut :

H1 kualitas produk berpengaruh positif terhadap citra merek (Brand Image).

Gilaninia dan Mousavian (2012) mengatakan bahwa brand image (citra merek) sering digunakan sebagai syarat ekstrinsik untuk membuat sebuah keputusan pembelian. Jika konsumen tidak memiliki pengalaman dengan suatu produk, mereka cenderung untuk mempercayai merek yang disukai atau yang terkenal (Schiffman dan Kanuk 2008).

Sebuah merek yang memiliki citra yang positif atau disukai dianggap dapat mengurangi resiko pembelian. Hal inilah yang menyebabkan para konsumen seringkali menggunakan brand image sebuah produk sebagai salah satu acuan dalam membuat sebuah keputusan pembelian. Hasil penelitian Paramitasari (2013), Gusniar (2010), mengenai pengaruh citra merk (brand image) terhadap keputusan pembelian memiliki pengaruh yang positif dan signifikan. Mengacu pada uraian diatas maka peneliti membuat hipotesis kedua sebagai berikut :

\section{H2 citra merk (brand image) berpengaruh positif terhadap keputusan}

Kualitas produk di dalam sebuah perusahaan sangat berperan penting karena apabila masyarakat sudah menggunakan produk yang berkualitas baik maka ia akan menggunakan produk tersebut secara berulang-ulang dan akan menjadi kebutuhan. Sehingga sangat memicu dalam pengambilan keputusan pembelian konsumen.

Hasil penelitian mengenai pengaruh kualitas produk terhadap keputusan pembelian dilakukan oleh Prabowo (2013), dan Baihakki (2013) menunjukan bahwa kualitas produk berpengaruh positif dan signifikan terhadap keputusan pembelian.

Mengacu pada uraian diatas maka peneliti membuat hipotesis ketiga sebagai berikut :

\section{H3 kualitas produk berpengaruh positif terhadap keputusan pembelian.}

Citra merek (Brand image) dan kualitas produk merupakan dua hal yang sangat berkaitan. Brand Image merupakan suatu hal yang penting agar produk dapat masuk kedalam ingatan masyarakat sehingga masyarakat tidak akan ragu dalam menggunakan produk 


\section{URNAL EKOBIS: EKONOMI, BISNIS \& MANAJEMEN Vol X Nomor X (year)}

tersebut. Akan tetapi bila kualitasnya kurang baik maka akan mengurangi volume penjualan produk dan akan mempengaruhi keputusan pembelian. Masih sedikit peneliti yang meneliti pengaruh tidak langsung antara kualitas produk terhadap keputusan pembelian melalui citra merk (brand image).

Mengacu pada uraian diatas maka peneliti membuat hipotesis keempat sebagai berikut :

H4 kualitas produk terhadap keputusan pembelian melalui citra merk (brand image).

Keterkaitan antara kualitas produk, citra merk dan keputusan pembelian berdasarkan teori dan peneliti terdahulu secara skematis dapat digambarkan dalam kerangka pikir seperti gambar dibawah ini:

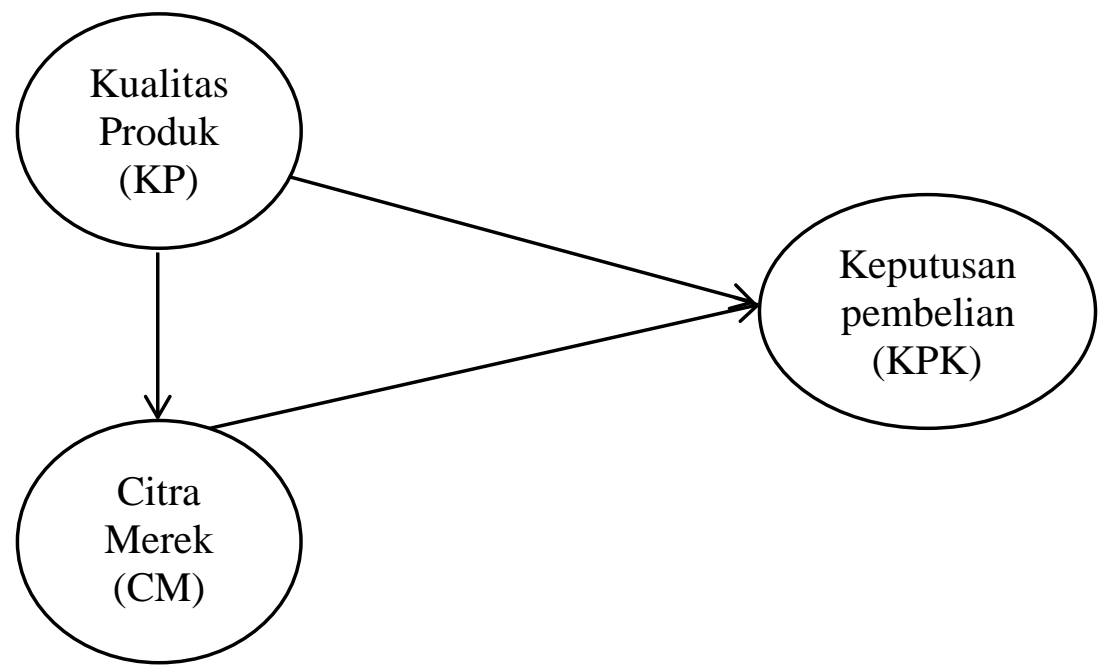

Gambar 1. Kerangka Pemikiran

\section{METODE PENELITIAN}

Sampel dalam penelitian ini adalah 100 responden pada konsumen alfamart kramat pulo 2 dengan teknik pengambilan sample non probability sampling yaitu yaitu teknik pengambilan sampel yang memberikan peluang yang sama bagi setiap unsur (anggota) populasi untuk dipilih menjadi anggota sampe.

Tabel 1. Operasional Variabel

\begin{tabular}{|c|c|c|}
\hline Variabel & Konsep variabel & Indikator \\
\hline $\begin{array}{l}\text { Kualitas Produk } \\
\text { (KP) }\end{array}$ & $\begin{array}{l}\text { Menurut Kotler dan Armstrong } \\
\text { (2012:283) } \\
\text { "Kualitas produk adalah } \\
\text { kemampuan sebuah produk dalam } \\
\text { memperagakan fungsiya, hal ini } \\
\text { termasuk keseluruhan durabilitas, } \\
\text { reliabilitas, ketepatan, kemudahan } \\
\text { pengoperasian, dan reparasi produk, } \\
\text { juga atribut produk lainnya". }\end{array}$ & 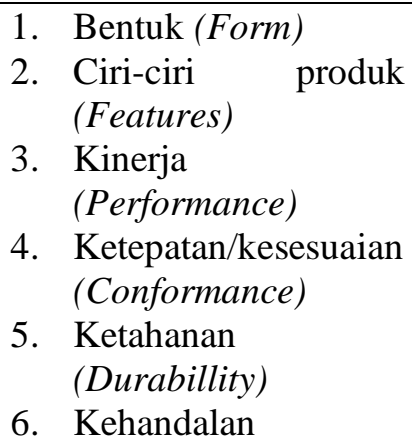 \\
\hline
\end{tabular}




\begin{tabular}{|c|c|c|}
\hline & & $\begin{aligned} & \begin{array}{l}\text { (Reliabillity) } \\
\text { 7. }\end{array} \\
& \text { Kemudahan } \\
& \text { perbaikan } \\
& \text { (repairabillity) } \\
& \text { 8. } \text { Gaya (Style) } \\
& \text { 9. } \text { Desain (Design) }\end{aligned}$ \\
\hline $\begin{array}{l}\text { Citra Merek (Brand } \\
\text { Image) }(\mathrm{CM})\end{array}$ & $\begin{array}{l}\text { Surachman (2008) mendefinisikan } \\
\text { citra merek sebagai bagian dari } \\
\text { merek yang dapat dikenali namun } \\
\text { tidak dapat diucapkan, seperti } \\
\text { lambang, desain huruf atau warna } \\
\text { khusus, atau persepsi pelanggan } \\
\text { atas sebuah produk atau jasa yang } \\
\text { diwakili oleh mereknya. }\end{array}$ & $\begin{array}{ll}\text { 1. } & \text { Kekuatan (strength) } \\
\text { 2. } & \text { Keunikan (uniquesnes) } \\
\text { 3. } & \text { Keunggulan } \\
& \text { (Favorable) }\end{array}$ \\
\hline $\begin{array}{l}\text { Keputusan Pembelian } \\
\text { Konsumen } \\
\text { (KPK) }\end{array}$ & $\begin{array}{l}\text { Pada umumnya, keputusan } \\
\text { pembelian konsumen adalah } \\
\text { membeli merek yang paling disukai } \\
\text { (Kotler dan Amstrsong, 2008). }\end{array}$ & $\begin{array}{ll}\text { 1. Pengenalan masalah } \\
\text { 2. Pencarian informasi } \\
\text { 3. Evaluasi alternative } \\
\text { 4. Keputusan } \\
\text { pembelian } \\
\text { 5. Perilaku Pasca } \\
\text { pembelian }\end{array}$ \\
\hline
\end{tabular}

Sumber : Peneliti Sebelumnya

Penelitian ini menggunakan pendekatan First Order Confirmatory. Konstruk laten kualitas produk diukur oleh indikator X1.1-X1.9 Konstruk laten citra merek diukur oleh indikator X2.1 -X2.3. Konstruk laten keputusan pembelian konsumen diukur oleh indikator Y1.1 - Y1.5

H3 kualitas produk berpengaruh positif terhadap keputusan pembelian. 
Berikut ini adalah gambar Full Structural Equetion Modelling penelitian ini:

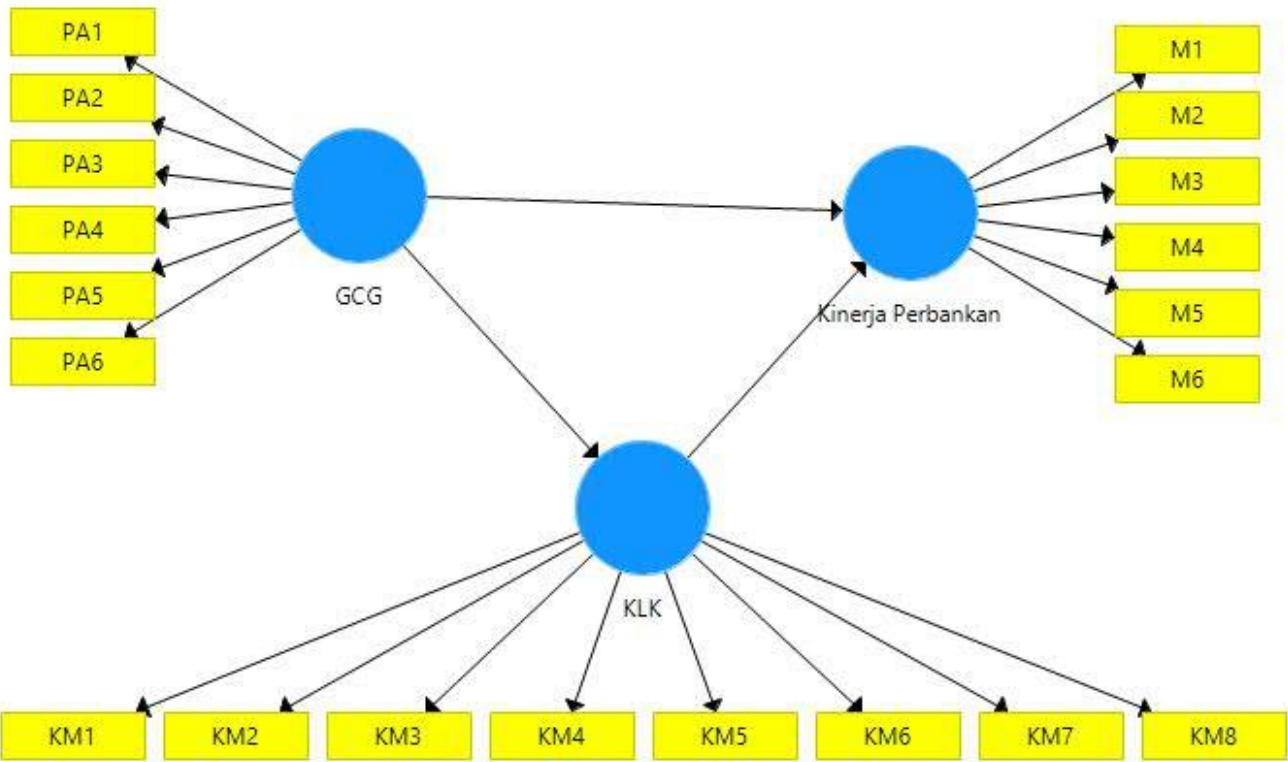

Gambar 2. Model SEM

Berdasarkan gambar model penelitian di atas, kemudian diterjemahkan ke dalam bentuk persamaan sebagai berikut :

$\mathrm{CM}=\mathrm{b}_{1} \mathrm{KP}+\mathrm{e}$

$\mathrm{KPK}=\mathrm{b}_{1} \mathrm{KP}+\mathrm{b}_{2} \mathrm{CM}+\mathrm{b}_{3} \mathrm{KPCM}+\mathrm{e}$.

Keterangan:

CM : Citra Merek

KP : Kualitas Produk

KPK : Keputusan Pembelian Konsumen

KPCM: Intervening Citra Merk

e : Error

Pengujian hipotesis dilakukan dengan membandingkan t-statistik dengan t-tabel atau dengan membandingkan nilai p-value (Wati, 2017). 
PEMBAHASAN

Analisis Deskripsi

Pada tahapan ini akan dilakukan analisis terhadap variabel-variabel penelitian berdasarkan item pertanyaan dalam kuesioner. Variabel Kualitas Produk terdiri dari sepuluh indikator pertanyaan yaitu X1.1 - X1.10, Variabel Citra Merk (Brand Image) mempunyai sepuluh indikator X2.1 $\mathrm{X} 2.10$, Variabel Keputusan pembelian terdiri dari sepuluh item pertanyaan yaitu Y1 - Y10. Deskripsi dari variabel - variabel penelitian tersebut dijelaskan pada tabel 2 sebagai berikut.

Tabel 2. Deskripsi Variabel Penelitian Kualitas Produk

\begin{tabular}{|c|c|c|c|c|c|c|c|c|c|c|c|}
\hline \multirow{2}{*}{$\begin{array}{l}\text { Variabel } \\
\& \text { Item } \\
\text { pertanya } \\
\text { an }\end{array}$} & \multicolumn{2}{|c|}{1} & \multicolumn{2}{|c|}{2} & \multicolumn{2}{|c|}{3} & \multicolumn{2}{|c|}{4} & \multicolumn{2}{|c|}{5} & \multirow{2}{*}{ Mean } \\
\hline & $\mathrm{F}$ & $\%$ & $\mathrm{~F}$ & $\%$ & $\mathrm{~F}$ & $\%$ & $\mathrm{~F}$ & $\%$ & $\mathrm{~F}$ & $\%$ & \\
\hline X.1.1 & 6 & 6 & 29 & 29 & 44 & 44 & 17 & 17 & 4 & 4 & 2,84 \\
\hline X.1.2 & 9 & 9 & 24 & 24 & 47 & 47 & 20 & 20 & 0 & 0 & 2,78 \\
\hline X.1.3 & 0 & 0 & 26 & 26 & 38 & 38 & 32 & 32 & 4 & 4 & 3,14 \\
\hline X.1.4 & 2 & 2 & 4 & 4 & 48 & 48 & 35 & 35 & 11 & 11 & 3,49 \\
\hline X.1.5 & 0 & 0 & 5 & 5 & 59 & 59 & 28 & 28 & 8 & 8 & 3,39 \\
\hline X.1.6 & 3 & 3 & 16 & 16 & 40 & 40 & 33 & 33 & 8 & 8 & 3,27 \\
\hline X.1.7 & 30 & 30 & 36 & 36 & 12 & 12 & 15 & 15 & 7 & 7 & 2,33 \\
\hline X.1.8 & 39 & 39 & 21 & 21 & 10 & 10 & 25 & 25 & 5 & 5 & 2,36 \\
\hline X.1.9 & 4 & 4 & 16 & 16 & 39 & 39 & 36 & 36 & 5 & 5 & 3,22 \\
\hline X.1.10 & 18 & 18 & 26 & 26 & 35 & 35 & 19 & 19 & 2 & 2 & 2,61 \\
\hline
\end{tabular}

Sumber : SPSS 21.0

Berdasarkan tabel diatas item item pertanyaan variabel Kualitas Produk memiliki means sebesar 2,94 yang berarti memiliki kecenderungan respon negatif. Artinya dalam hal ini responden yang merupakan pelanggan alfamart merasa bahwa kualitas yang dimiliki alfamart belum sesuai dengan harapan para pelanggan. Respon negatif tertinggi adalah indikator X1.7 sebesar 2,33 yang artinya bahwa penampilan atau kemasan dari produk berlabel Alfamart belum menarik, sementara respon negatif tertinggi selanjutnya adalah indicator X1.8 yaitu sebesar 2,36 yang berarti produk dari Alfamart belum memiliki desain yang istimewa, dan respon negatif juga terdapat pada indikator X1.10 dimana memiliki arti bahwa kualitas produk dari Alfamart masih diragukan dibandingkan dengan produk lainnya.

Tabel 3. Deskripsi Variabel Penelitian Citra Merek (Brand Image)

\begin{tabular}{|c|c|c|c|c|c|c|c|c|c|c|c|}
\hline \multirow{2}{*}{$\begin{array}{l}\text { Variabel } \\
\& \quad \text { Item } \\
\text { pertanyaa } \\
\text { n }\end{array}$} & \multicolumn{2}{|c|}{1} & \multicolumn{2}{|c|}{2} & \multicolumn{2}{|c|}{3} & \multicolumn{2}{|c|}{4} & \multicolumn{2}{|c|}{5} & \multirow{2}{*}{ Mean } \\
\hline & $\mathrm{F}$ & $\%$ & $\mathrm{~F}$ & $\%$ & $\mathrm{~F}$ & $\%$ & $\mathrm{~F}$ & $\%$ & $\mathrm{~F}$ & $\%$ & \\
\hline X.2.1 & 4 & 4 & 12 & 12 & 33 & 33 & 45 & 45 & 6 & 6 & 3,37 \\
\hline X.2.2 & 26 & 26 & 21 & 21 & 23 & 23 & 25 & 25 & 5 & 5 & 2,62 \\
\hline X.2.3 & 1 & 1 & 14 & 14 & 25 & 25 & 50 & 50 & 10 & 10 & 3,54 \\
\hline
\end{tabular}




\begin{tabular}{|c|c|c|c|c|c|c|c|c|c|c|c|} 
X.2.4 & 13 & 13 & 37 & 37 & 25 & 25 & 20 & 20 & 5 & 5 & 2,67 \\
\hline X.2.5 & 3 & 3 & 24 & 24 & 43 & 43 & 21 & 21 & 9 & 9 & 3,09 \\
\hline X.2.6 & 15 & 15 & 36 & 36 & 22 & 22 & 25 & 25 & 2 & 2 & 2,63 \\
\hline X.2.7 & 18 & 18 & 36 & 36 & 21 & 21 & 18 & 18 & 7 & 7 & 2,60 \\
\hline X.2.8 & 1 & 1 & 7 & 7 & 22 & 22 & 52 & 52 & 18 & 18 & 3,79 \\
\hline X.2.9 & 2 & 2 & 16 & 16 & 33 & 33 & 42 & 42 & 7 & 7 & 3,36 \\
\hline X.2.10 & 2 & 2 & 24 & 24 & 39 & 39 & 31 & 31 & 4 & 4 & 3,11 \\
\hline \multicolumn{9}{|c|}{ Mean } \\
\hline
\end{tabular}

Sumber : SPSS 21.0

Variabel yang kedua yaitu Citra Merk, dimana mempunyai nilai means diatas 3 yaitu sebesar 3,07 yang berarti memiliki kecenderungan respon negatif. Pada indikator X.2.7 mempunyai respon negatif tertinggi sebesar 2,60 yang artinya bahwa produk berlabel Alfamart belum menjadi produk favorit konsumen, respon negatif tertinggi kedua terdapat pada indikator X2.2 yaitu sebesar 2,62 yang artinya desain dari produk Alfamart belum berinovasi, sementara pada indikator X2.6 memiliki respon negatif sebesar 2,63 dimana memiliki arti bahwa produk Alfamart belum memiliki variasi yang sesuai dengan kebutuhan konsumen, dan selanjutnya pada indikator X2.4 juga memiliki respon negatif sebesar 2,67 yang artinya produk berlabel Alfamart masih jarang ditampilkan dalam iklan.

\section{Tabel 4. Deskripsi Variabel Penelitian Keputusan pembelian}

\begin{tabular}{|c|c|c|c|c|c|c|c|c|c|c|c|}
\hline \multirow{2}{*}{$\begin{array}{c}\text { Variabel } \\
\& \text { Item } \\
\text { pertanyaa } \\
n\end{array}$} & \multicolumn{2}{|c|}{1} & \multicolumn{2}{|c|}{2} & \multicolumn{2}{|c|}{3} & \multicolumn{2}{|c|}{4} & \multicolumn{2}{|c|}{5} & \multirow{2}{*}{ Mean } \\
\hline & $\mathrm{F}$ & $\%$ & $\mathrm{~F}$ & $\%$ & $\mathrm{~F}$ & $\%$ & $\mathrm{~F}$ & $\%$ & $\mathrm{~F}$ & $\%$ & \\
\hline Y.1 & 1 & 1 & 22 & 22 & 32 & 32 & 36 & 36 & 9 & 9 & 3,30 \\
\hline Y.2 & 1 & 1 & 10 & 10 & 28 & 28 & 57 & 57 & 4 & 4 & 3,53 \\
\hline Y.3 & 3 & 3 & 35 & 35 & 36 & 36 & 19 & 19 & 7 & 7 & 2,92 \\
\hline Y.4 & 3 & 3 & 36 & 36 & 26 & 26 & 28 & 28 & 7 & 7 & 3,00 \\
\hline Y.5 & 3 & 3 & 21 & 21 & 30 & 30 & 40 & 40 & 6 & 6 & 3,25 \\
\hline Y.6 & 6 & 6 & 37 & 37 & 30 & 30 & 21 & 21 & 6 & 6 & 2,84 \\
\hline Y.7 & 1 & 1 & 9 & 9 & 43 & 43 & 32 & 32 & 15 & 15 & 3,51 \\
\hline Y.8 & 1 & 1 & 14 & 14 & 44 & 44 & 35 & 35 & 6 & 6 & 3,31 \\
\hline Y.9 & 1 & 1 & 26 & 26 & 45 & 45 & 18 & 18 & 10 & 10 & 3,10 \\
\hline Y.10 & 20 & 20 & 42 & 42 & 18 & 18 & 14 & 14 & 6 & 6 & 2,44 \\
\hline & & & & & & & & & & & 3,12 \\
\hline
\end{tabular}

Sumber : SPSS 21.0

Variabel yang ketiga yaitu keputusan pembelian, dimana memiliki means sebesar 3,12 yang berarti memiliki kecenderungan respon negatif. Pada indikator Y10 memiliki respon negatif tertinggi sebesar 2,44 yang artinya bahwa jika tidak ada produk Alfamart, maka konsumen tidak akan kesulitan mencari produk pengganti, respon negatif tertinggi kedua terdapat pada indikator Y6 yaitu sebesar 2,84 yang memiliki arti produk berlabel Alfamart belum menjawab kebutuhan konsumen sehari-hari atau belum memenuhi kebutuhan konsumen sehari hari, selanjutnya 
respon negatif terdapat pada indikator Y3 sebesar 2,93 yang artinya responden yang membeli produk Alfamart tidak mendapatkan informasi dari rekan yang telah menggunakan produk tersebut, dan respon negatif juga terdapat pada indikator Y4 sebesar 3,00 yang artinya bahwa konsumen mengenal produk berlabel Alfamart bukan dari masyarakat.

\section{Uji Validitas}

Berikut ini adalah hasil output factor loading konstruk kualitas produk, citra merk dan keputusan pembelian pada PLS :

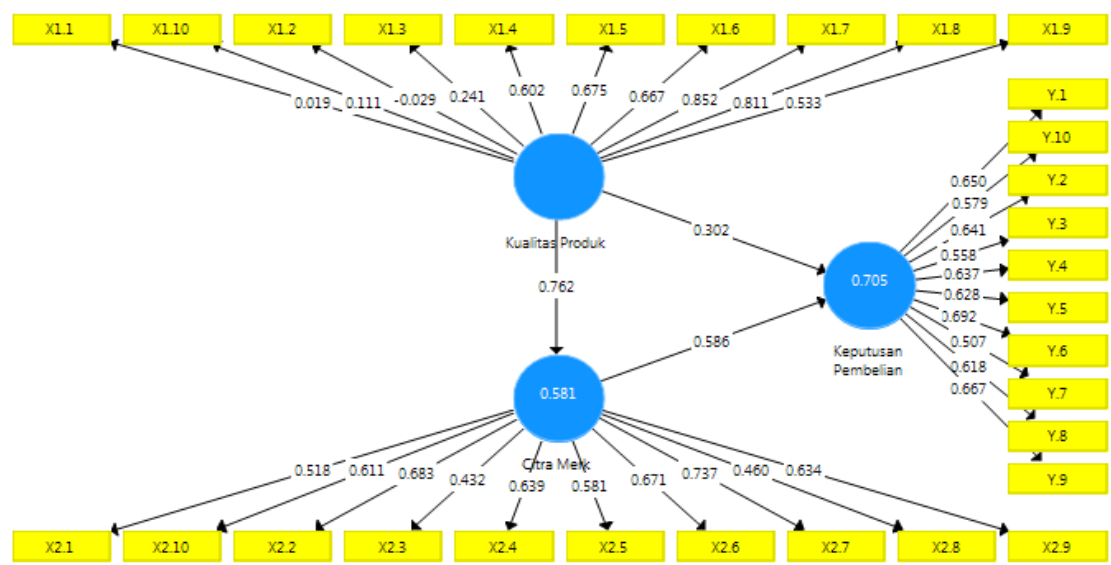

Gambar 3. Loading Factor Variabel Penelitian Sebelum di Drop Sumber : Hasil diolah Smart PLS

Berdasarkan nilai factor loading di atas, masih terdapat faktor loading yang nilainya di bawah 0.5 . Karena memiliki nilai convergent validity yang rendah, maka item- item pertanyaan yang memiliki loading factor di bawah 0.5 tersebut harus di drop, berdasarkan output di atas indikator X1.1, X1.2, X1.3, X1.10, X2.1, X2.3, X2.8, Y7 loadingnya di bawah 0.5 sehingga indikator tersebut harus di drop. Untuk lebih jelasnya Tabel 5 berikut ini mendeskripsikan faktor loading dan nilai $\mathrm{T}_{\text {statistik }}$ untuk masing masing indikator:

Tabel 5. Uji Validitas

\begin{tabular}{|c|c|c|c|c|c|c|}
\hline \multirow[b]{2}{*}{ Variabel } & \multirow[b]{2}{*}{ Indikator } & \multirow[b]{2}{*}{ loading } & \multicolumn{3}{|c|}{ T-statistik } & \multirow[b]{2}{*}{ Keterangan } \\
\hline & & & $\begin{array}{c}\text { Kualitas } \\
\text { produk } \\
\text { (KP) }\end{array}$ & $\begin{array}{l}\text { Citra } \\
\text { merk } \\
(\mathrm{CM})\end{array}$ & $\begin{array}{c}\text { Keputusan } \\
\text { pembelian } \\
(\mathrm{KPK})\end{array}$ & \\
\hline \multirow{10}{*}{$\begin{array}{c}\text { Kualitas } \\
\text { produk } \\
\text { (KP) }\end{array}$} & $\mathrm{X} 1.1$ & 0,019 & 0,133 & & & $\begin{array}{c}\text { Tidak valid dan } \\
\text { signifikan }\end{array}$ \\
\hline & $\mathrm{X} 1.2$ & $-0,029$ & 0,216 & & & $\begin{array}{l}\text { Tidak valid dan } \\
\text { signifikan }\end{array}$ \\
\hline & $\mathrm{X} 1.3$ & 0,241 & 1,619 & & & $\begin{array}{l}\text { Tidak valid dan } \\
\text { signifikan }\end{array}$ \\
\hline & $\mathrm{X} 1.4$ & 0,602 & 5,781 & & & Valid dan signifikan \\
\hline & $\mathrm{X} 1.5$ & 0,675 & 7,903 & & & Valid dan signifikan \\
\hline & $\mathrm{X} 1.6$ & 0,667 & 10,939 & & & Valid dan signifikan \\
\hline & $\mathrm{X} 1.7$ & 0,852 & 30,081 & & & Valid dan signifikan \\
\hline & $\mathrm{X} 1.8$ & 0,811 & 25,263 & & & Valid dan signifikan \\
\hline & $\mathrm{X} 1.9$ & 0,533 & 5,873 & & & Valid dan signifikan \\
\hline & $\mathrm{X} 1.10$ & 0,111 & 0,634 & & & Tidak valid dan \\
\hline
\end{tabular}




\begin{tabular}{|c|c|c|c|c|c|}
\hline & & & & & signifikan \\
\hline \multirow{10}{*}{$\begin{array}{l}\text { Citra merk } \\
\text { (Brand } \\
\text { Image) } \\
\text { (CM) }\end{array}$} & $\mathrm{X} 2.1$ & 0,518 & 6,024 & & Valid dan signifikan \\
\hline & $\mathrm{X} 2.2$ & 0,683 & 14,364 & & Valid dan signifikan \\
\hline & $\mathrm{X} 2.3$ & 0,432 & 4,857 & & $\begin{array}{l}\text { Tidak valid dan } \\
\text { signifikan }\end{array}$ \\
\hline & $\mathrm{X} 2.4$ & 0,639 & 9,554 & & Valid dan signifikan \\
\hline & $\mathrm{X} 2.5$ & 0,581 & 6,966 & & Valid dan signifikan \\
\hline & $\mathrm{X} 2.6$ & 0,671 & 11,744 & & Valid dan signifikan \\
\hline & $\mathrm{X} 2.7$ & 0,737 & 14,349 & & Valid dan signifikan \\
\hline & $\mathrm{X} 2.8$ & 0,460 & 4,976 & & $\begin{array}{c}\text { Tidak valid dan } \\
\text { signifikan }\end{array}$ \\
\hline & $\mathrm{X} 2.9$ & 0,634 & 7,319 & & Valid dan signifikan \\
\hline & $\mathrm{X} 2.10$ & 0,611 & 6,604 & & Valid dan signifikan \\
\hline \multirow{10}{*}{$\begin{array}{c}\text { Keputusan } \\
\text { pembelian } \\
\text { (KPK) }\end{array}$} & $\mathrm{Y} 1$ & 0,650 & & 11,828 & Valid dan signifikan \\
\hline & Y2 & 0,641 & & 10,825 & Valid dan signifikan \\
\hline & Y3 & 0,558 & & 6,024 & Valid dan signifikan \\
\hline & Y4 & 0,637 & & 9,266 & Valid dan signifikan \\
\hline & Y5 & 0,628 & & 9,458 & Valid dan signifikan \\
\hline & Y6 & 0,692 & & 13,750 & Valid dan signifikan \\
\hline & Y7 & 0,507 & & 4,109 & $\begin{array}{l}\text { Tidak valid dan } \\
\text { signifikan }\end{array}$ \\
\hline & Y8 & 0,618 & & 8,489 & Valid dan signifikan \\
\hline & Y9 & 0,667 & & 7,853 & Valid dan signifikan \\
\hline & Y10 & 0,579 & & 5,073 & Valid dan signifikan \\
\hline
\end{tabular}

Sumber: Hasil diolah Smart PLS

Karena ada indikator yang tidak valid dan harus didrop, maka harus dilakukan analisis kembali. Berikut ini adalah hasil output yang telah diperbaiki:

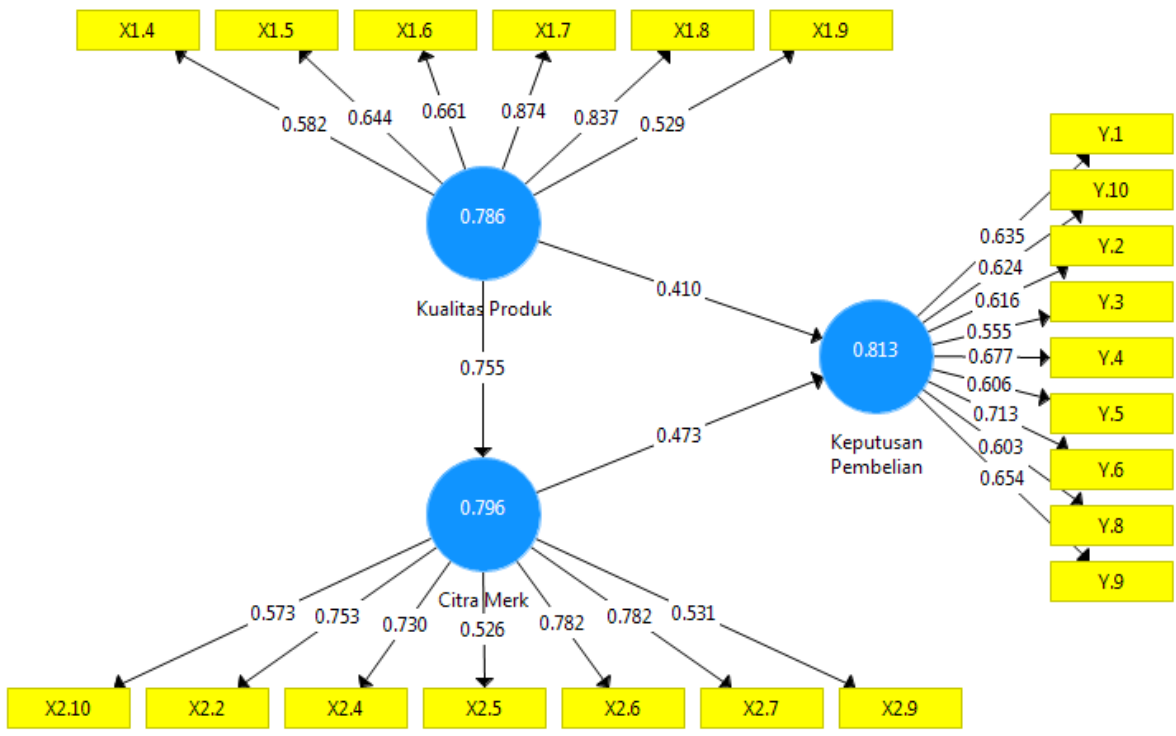

Gambar 4. Reloading Factor Variabel Penelitian

Sumber: Hasil diolah Smart PLS 
Berdasarkan output pada diagram jalur di atas, factor loading sudah memenuhi convergent validity yaitu nilai indikatornya sudah di atas 0.5 .

\section{Pengujian Reliabilitas}

Dalam penelitian, suatu variabel dikatakan cukup reliabilitas bila variabel tersebut mempunyai nilai construct reliability lebih besar dari 0,6. Berikut ini adalah tabel hasil pengujian reliabilitas pada masing-masing variabel penelitian:

Tabel 6. Uji Reliabilitas

\begin{tabular}{|c|c|c|c|}
\hline VARIABEL & AVE & $\begin{array}{c}\text { Compsite } \\
\text { reability }\end{array}$ & $\begin{array}{c}\text { Cronbachs } \\
\text { alpha }\end{array}$ \\
\hline Kualitas Produk (KP) & 0,489 & 0,847 & 0,786 \\
\hline Citra Merk (CM) & 0,459 & 0,852 & 0,796 \\
\hline Keputusan Pembelian (KPK) & 0,400 & 0,857 & 0,813 \\
\hline
\end{tabular}

Sumber: Hasil diolah Smart PLS

Berdasarkan hasil output reliabilitas diatas, dapat disimpulkan bahwa untuk variabel kualitas produk, citra merk dan keputusan pembelian memiliki composite reliability di atas 0,8 dan cronbachs alpha di atas 0,7 sehingga dapat disimpulkan bahwa indikator-indikator yang digunakan pada masing-masing variabel mempunyai reabilitas yang baik atau mampu untuk mengukur konstruknya.

Inner Model (Godness Of Fit Model) $\left(R^{2}\right)$

Evaluasi Goodness of Fit Model diukur dengan menggunakan nilai predictive relevance $\left(Q^{2}\right)$. Nilai predictive relevance $\left(Q^{2}\right)$ dihitung dengan menggunakan rumus sebagai berikut :

$Q^{2}=1-\left(1-\mathrm{R}^{2}\right)\left(1-\mathrm{R}^{2}{ }_{2}\right)$

$Q^{2}=1-(1-0,570)(1-0,684)$

$=1-(0,43)(0,316)$

$=1-0,1359$

$Q^{2}=0,8641$

Dimana $\mathrm{R}^{2}$ dan $\mathrm{R}^{2}$ merupakan $\mathrm{R}$.square variabel endogen dalam model Interprestasi $\mathrm{Q}^{2}$ sama dengan koefisien determinasi total pada analisis jalur (mirip dengan $R^{2}$ pada regresi). $R^{2}$ adalah koefisien determinasi yang merupakan bagian dari variasi total dalam variabel dependen yang dijelaskan oleh variasi dalam variabel independen Tabel 4.1.7 berikut ini menjelaskan hasil analisis koefisien determinasi dari variabel-variabel penelitian :

Tabel 7. R Square

\begin{tabular}{|c|c|}
\hline Variabel & R.Square \\
\hline Citra merk & 0,570 \\
\hline Keputusan pembelian & 0,684 \\
\hline Predictive Relevance $(Q 2)$ & 0,864 \\
\hline
\end{tabular}

Sumber: Hasil diolah Smart PLS

Berdasarkan model penelitian diatas, diperoleh nilai $\left(\mathrm{R}^{2}\right)$ dari variabel citra merk sebesar 0.570 , yang artinya nilai tersebut mengindikasikan bahwa citra merk dapat dijelaskan oleh variabel kualitas produk sebesar 57\% sedangkan sisanya yaitu sebesar $43 \%$ dipengaruhi oleh variabel lain yang tidak terdapat dalam penelitian dan variabel keputusan pembelian konsumen sebesar 0.684 , yang artinya nilai tersebut mengindikasikan bahwa variasi keputusan pembelian dapat dijelaskan oleh variabel kualitas produk dan citra merk sebesar $68.4 \%$ sedangkan sisanya yaitu sebesar $31.6 \%$ dipengaruhi oleh variabel lain yang tidak terdapat dalam model penelitian. Sedangkan nilai predictive-relevance untuk model struktural dalam penelitian ini adalah sebesar 0.864 atau $86.4 \%$, artinya model mampu menjelaskan fenomena keputusan pembelian dikaitkan dengan beberapa variabel, yaitu kualitas produk dan citra merk. Oleh karena itu model 
dapat dikatakan sangat baik, atau model memiliki nilai prediktif yang sangat baik. Pada akhirnya model dapat digunakan untuk penguji hipotesis.

\section{Pengujian Hipotesis}

Untuk menguji hipotesis dalam penelitian ini, digunakan nilai tstatistik pada masing-masing jalur pengaruh langsung secara parsial. Berikut ini adalah gambar yang menjelaskan diagram jalur untuk pengujian hipotesis:

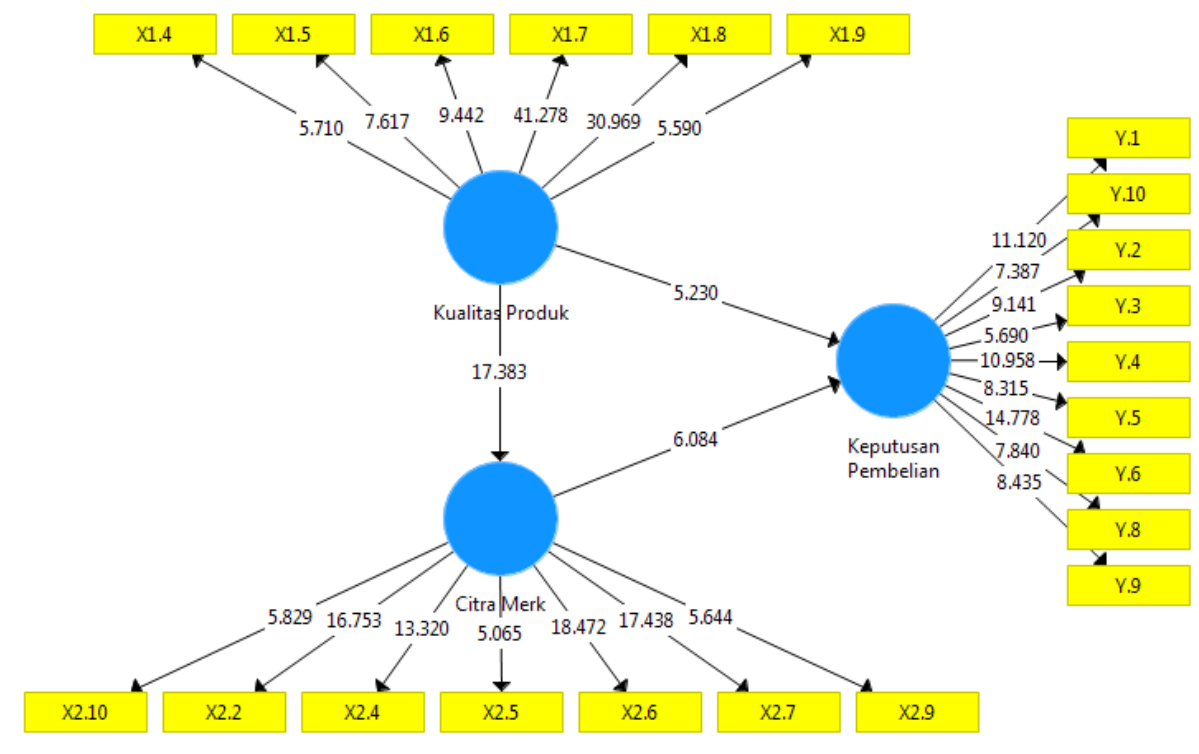

Gambar 5. Diagram Path pengujian hipotesis

Sumber: Data diolah Smart PLS

Berdasarkan diagram path pengujian hipotesis di atas, tidak semua indikator pada masingmasing variabel mempunyai nilai $t_{\text {statistics }}$ lebih besar dari 1.66 ('tabel). Untuk menguji hubungan antar variabel (uji hipotesis), maka digunakan nilai $t_{\text {statistik }}$ dari output Smart PLS yang dibandingkan dengan nilai tabel. Berikut ini adalah tabel yang memberikan hasil hubungan antar konstruk (variabel):

Tabel 8. Pengujian Hipotesis

\begin{tabular}{|c|c|c|c|c|c|}
\hline $\begin{array}{c}\text { Hubungan antar } \\
\text { variabel }\end{array}$ & $\begin{array}{c}\text { Koefisien } \\
\text { parameter }\end{array}$ & $\begin{array}{c}\text { Standar } \\
\text { error }\end{array}$ & $\begin{array}{c}\mathbf{T} \\
\text { statistics }\end{array}$ & $\begin{array}{c}\mathbf{P} \\
\text { Value }\end{array}$ & Keterangan \\
\hline $\begin{array}{c}\text { Kualitas produk => } \\
\text { Citra Merk }\end{array}$ & 0.755 & 0.045 & 16.908 & 0.000 & Signifikan*** \\
\hline $\begin{array}{c}\text { Citra merk => } \\
\text { Keputusan Pembelian }\end{array}$ & 0.473 & 0.080 & 5.893 & 0.000 & Signifikan*** \\
\hline $\begin{array}{c}\text { Kualitas produk => } \\
\text { Keputusan Pembelian }\end{array}$ & 0.410 & 0.079 & 5.166 & 0.000 & Signifikan*** \\
\hline $\begin{array}{c}\text { Kualitas produk => } \\
\text { Keputusan Pembelian } \\
\text { melalui variabel } \\
\text { intervening }\end{array}$ & 0.357 & 0.066 & 5.430 & 0.000 & Signifikan*** \\
\hline
\end{tabular}

Ket: ***Signifikan pada a 1\%, **Signifikan pada a 5\%, *Signifikan pada a 10\%

Sumber: Data diolah Smart PLS 


\section{Pengaruh Kualitas Produk Terhadap Citra Merk}

Berdasarkan hasil penelitian didapatkan hasil bahwa terdapat pengaruh positif dan signifikan antara kualitas produk terhadap citra merk. Hasil penelitian ini sejalan dengan penelitian yang dilakukan dilakukan oleh Anandia (2015), mengenai kualitas produk terhadap citra merek dan menjelaskan bahwa kualitas produk berpengaruh positif dan signifikan terhadap citra merek. Dengan demikian adanya kualitas produk yang baik dapat meningkatkan citra merk yang melekat dan masyarakat akan terus mengingat produk tersebut

\section{Pengaruh Citra Merk Terhadap Keputusan Pembelian}

Hasil penelitian ini menunjukan citra merk berpengaruh positif dan signifikan terhadap keputusan pembelian. Hal ini sejalan dengan penelitian yang dilakukan oleh Paramitasari (2013), Gusniar (2010), yang menjelaskan bahwa citra merek berpengaruh positif dan signifikan terhadap keputusan pembelian. Dengan demikian, keputusan pembelian konsumen sangat di pengaruhi oleh citra merk dari produk itu sendiri, semakin dikenal sebuah produk maka konsumen akan memutuskan untuk membeli produk tersebut.

\section{Pengaruh Kualitas Produk Terhadap Keputusan Pembelian}

Hasil penelitian ini menunjukan kualitas produk berpengaruh positif dan signifikan terhadap keputusan pembelian. Hal ini sejalan dengan penelitian yang dilakukan oleh Prabowo (2013) dan Baihakki (2013), yang menjelaskan bahwa kualitas produk berpengaruh positif dan signifikan terhadap keputusan pembelian, serta sejalan juga dengan Agustia (2009) yang menyatakan bahwa kualitas produk sudah baik dan sesuai dengan standarisasi, akan tetapi dalam hal desain masih memiliki nilai rendah artinya dari penelitian yang dilakukan oleh Agustia yang sudah berjalan selama 7 tahun dengan penelitian yang saya lakukan belum ada perubahan pada produk alfamart misalnya, pada kemasan produk Alfamart Gula, Tissu Alfamart, dan Alfamart Air mineral memiliki tampilan desain yang sama, dan penelitian ini tidak sejalan dengan penelitian terdahulu yang dilakukan oleh Taslim (2014), yaitu kualitas produk berpengaruh positif tetapi tidak signifikan terhadap keputusan pembelian, dan juga tidak sejalan dengan Fauziah (2013) yang menyatakan bahwa kualitas produk memiliki pengaruh negatif dan tidak signifikan terhadap keputusan pembelian. Dengan memperbaiki kualitas produk dan terus berinovasi dalam mendesain produk maka akan meningkatkan keputusan pembelian konsumen.

\section{Pengaruh Kualitas Produk Terhadap Keputusan Pembelian Melalui Citra Merk}

Hasil penelitian ini menunjukan kualitas produk berpengaruh positif dan signifikan terhadap keputusan pembelian melalui citra merk. Hal ini tidak sejalan dengan penelitian yang dilakukan oleh Erdwansyah (2013), yang menyatakan bahwa kualitas produk tidak berpengaruh pada keputusan pembelian melalui citra merek. Dengan demikian, hal yang harus ditingkatkan kembali yaitu kualitas produk dengan memberikan tampilan yang menarik dengan terus berinovasi dan mengikuti perkembangan jaman, dan melakukan pemasangan iklan atau promosi untuk terus mengembangkan citra merk dari produk berlabel Alfamart sehingga akan mempengaruhi konsumen dalam pengambilan keputusan.

\section{Penutup}

Berdasarkan hasil penelitian baik melalui analisis persepsi maupun analisis empiris, kualitas produk berpengaruh positif dan signifikan terhadap citra merk, sehingga jika kualitas produk semakin baik maka citra merk akan semakin meningkat. Secara empiris citra merk berpengaruh positif dan signifikan terhadap keputusan pembelian sehingga jika citra merk dari produk tersebut semakin melekat dibenak konsumen maka keputusan pembelian akan semakin meningkat. Selanjutnya pengujian secara empiris, kualitas produk berpengaruh positif dan signifikan terhadap keputusan pembelian. Pada hipotesis keempat, kualitas produk berpengaruh positif dan signifikan terhadap keputusan pembelian konsumen melalui citra merk. 
Keterbatasan peelitian ini Kurang kontrol dalam melakukan penyebaran kuesioner penelitian, hal ini dapat dilihat dari adanya item yang terbuang dikarenakan nilai responden yang diberikan pada item tersebut terlihat tidak serempak, yang setelah peneliti selidiki ternyata terdapat keambiguan kalimat pada item pertanyaan tersebut. Untuk itu untuk peneliti mendatang diharapkan menanyakan kepada responden mengenai item-item apa saja yang mungkin memiliki ketidak jelasan untuk menghindari terjadinya item pembuangan yang tidak valid dan selanjunya untuk penelitian mendatang, sebaiknya menambah sampel serta memperluas cakupan penelitian, dan diharapkan adanya variabel lain yang mempengaruhi kualitas produk, citra merk dan keputusan pembelian.

\section{Saran}

Penulis memberi saran pada alfamart untuk kualitas produk masih perlu meningkatkan perbaikan guna mengembangkan produk terutama dalam segi penampilan atau desain yang harus dibuat semenarik mungkin serta sesuai dengan jenis dan kegunaan dari produk tersebut, sehingga akan mempengaruhi konsumen untuk membeli produk tersebut. Dapat dilihat dari hasil penelitian yang sudah berjalan selama 7 tahun dengan penelitian yang saya lakukan mendapatkan hasil yang sama, dimana pada indikator kualitas produk sudah dinilai baik akan tetapi pada indikator desain masih dinilai rendah artinya belum ada perubahan fisik pada produk berlabel Alfamart. Contohnya pada kemasan produk Alfamart gula pasir, air mineral Alfamart, dan meises Alfamart memiliki desain yang sama, seharusnya desain pada produk-produk tersebut dibuat berbeda dan sesuai dengan jenis serta kegunaan dari produk tersebut. Sebaiknya Alfamart melakukan inovasi dalam desain untuk pengembangan produk dan membuat tampilan produk semenarik mungkin, sehingga akan membuat konsumen tertarik dan melakukan pembelian, serta menceritakan dan mereferensikan produk tersebut kepada masyarakat luas dan akan tercipta citra merk yang semakin melekat pada masyarakat. Pada faktor citra merk perlu adanya peningkatan citra merk dengan melakukan pengenalan produk lebih jauh lagi, hal ini dapat ditingkatkan melalui iklan, mengadakan promosi, dan selalu berinovasi dalam menciptakan produk baik dari segi cita rasa, penampilan, dan hal-hal lainnya yang memiliki ciri khas yang menarik sehingga dapat membuat produk tersebut terus melekat dan tertanam di hati konsumen. Selanjutnya untuk meningkatkan keputusan pembelian selain dengan meningkatkan kualitas produk dan meningkatkan citra merk yang baik, tentu saja perusahaan perlu untuk melakukan hal lain guna mengembangkan produk, yaitu melalui iklan di media agar masyarakat lebih mengenal, menciptakan produk yang lebih beragam, mempromosikan produk melalui spanduk, internet, dan media lainnya, serta memberikan harga yang lebih terjangkau dibandingkan produk lainnya.

\section{REFERENSI}

Ahmad Baihakki Zaini, (2013). Analisa Pengaruh Citra Merek, Kualitas Produk Dan Promosi Terhadap Keputusan Pembelian (Studi Kasus Pasta Gigi Pepsodent Di Wilayah Jakarta Timur)

Anita Anggraeni dan Hartiwi Prabowo, 2013, Analisis Pengaruh Persepsi Kualitas dan Citra Merek terhadap Kepuasan Pelanggan dan Dampaknya pada Pembelian Ulang (Studi Kasus : Pelanggan Majalah Mix di Jakarta Selatan, Journal E Prints Binus, 23471

Bella Gusniar, (2011). Pengaruh Citra Merek, Harga dan Kualitas Produk terhadap Proses Keputusan Pembelian Produk Hand and Body Lotion.

Fauziah, Utin. Hairida. dan Melati, H.A. 2013. "Peningkatan Efektifitas dan Hasil Belajar Siswa Melalui Strategi True Or False Berbantuan Media Flash.’Diakses ada tanggal 25 April 2016

Gilaninia, Shahram dan Seyyed J. Mousavian. 2011. The Investigation and Analysis Impact of Brand Image in Iran. African Journal of Business Management, (6)25: 75487556

Kotler, Philip dan Lane Keller. 2007. Prinsip- Prinsip Manajemen Pemasaran.

Jakarta :Salemba Empat. 
Kottler, P \& Amstorng, G. 2008. Prinsip - Prinsip Pemasaran.Erlangga;Jakarta.

Puspita Dwi Suci, Taslim, Fitriani Anita 2014. Pengaruh harga, kualitas produk, dan citra merek terhadap keputusan pembelian yogurt (survey pada konsumen yogurt youljell PT insan Muda Berdikari). Universitas padjadjaran.

Paramitasari fransisca musay, 2013 "pengaruh brand image terhadap keputusan pembeian (survei pada konsumen KFC Kawi Malang) falkultas ilmu administrasi universitas brawijaya

Rizky, Anandia. 2015. Analisa Pengaruh Desain Produk, Persepsi Harga, dan Kualitas Produk Terhadap Citra Merek untuk Meningkatkan Minat Beli Konsumen Sepatu Adidas Original (Studi Kasus pada Masyarakat di Kota Semarang) Fakultas Ekonomika dan Bisnis Universitas Diponegoro Semarang. Vol. 4, No. 3.

Surachman. 2008. Dasar-Dasar Manajemen Merek (Alat Pemasaran Untuk Memenangkan Persaingan). Malang: Bayumedia Publishing.

Wati, Lela Nurlaela. 2017. "Metodologi Penelitian Bisnis Terapan, Aplikasi SPSS, Eviews, Smart PLS dan AMOS". Penerbit Mujahid Press: Bandung. 